\title{
Shrub encroachment of Iberian dehesas: implications on total forage productivity
}

\author{
M. L. López-Díaz • V. Rolo • R. Benítez • \\ G. Moreno
}

\begin{abstract}
The Iberian dehesa, a grazed Mediterranean open woodland, is an outstanding example of a silvopastoral system. Shrub encroachment has been proposed as an effective method to facilitate natural tree regeneration and ensure the sustainability of silvopastoral systems. At the same time, shrubs can affect both pasture understory and tree overstory production. The effects of varying intensities of shrub encroachment on the productivity of four forage components of this system-pasture, acorns, shrub browse and tree browse-were tested and the overall metabolisable energy (ME) under different scenarios of vegetation structure was calculated. Two common shrub species with contrasting plant architectures and ecological functions were studied as models: Cistus ladanifer and Retama sphaerocarpa. Cistus negatively affected acorn, tree browse and pasture production, whereas Retama positively affected pasture and browse production and was neutral for acorn
\end{abstract}

M. L. López-Díaz ( ) · G. Moreno

Forestry Research Group, University of Extremadura,

Plasencia, Spain

e-mail: lurdesld@unex.es

V. Rolo

Conservation Ecology Research Unit, University of

Pretoria, Pretoria, South Africa

R. Benítez

Department of Mathematics, University of Extremadura, Avda. Virgen del Puerto no. 2, 10600 Plasencia, Cáceres, Spain production. The highest ME values were found when tree cover was ca. $70 \%$ and $C$. ladanifer cover was low or $R$. sphaerocarpa cover was medium. The authors recommend conserving and promoting patched three-layered plots in Iberian dehesas and similar extensive silvopastoral systems where certain shrub species could simultaneously encourage the sustainability of these systems and reinforce (with $R$. sphaerocarpa) or maintain (with $C$. ladanifer) their productivity.

Keywords Forage shrub - Acorn production - Cistus ladanifer · Retama sphaerocarpa $\cdot$ Pasture yield

\section{Introduction}

Scattered tree ecosystems occur throughout the world, either naturally, such as savannas and sparse woody steppes, or as man-made open woodlands, like the Iberian dehesas (Manning et al. 2006; Moreno and Pulido 2009). A dehesa is usually defined as a twolayered silvopastoral system in which native grasses cohabit with a layer of scattered, widely spaced trees, mostly of the Quercus genus. The most important commercial production on a dehesa is extensive livestock husbandry, especially when the predominant species is $Q$. ilex. The dehesa diet is characterised by diversified forage production composed mainly of pasture, fruits and nuts (acorns), and shrub and tree 
browse. Livestock feed primarily on pasture, but browse and acorns also provide them with important nutritional resources. These complementary resources are typically consumed at the end of summer or during winter, when pasture is scarce due to intra-annual differences in production.

In recent decades, dehesas have experienced several management changes, leading many authors to question the sustainability of this agroforestry system, at least under current management practices. Soil erosion, failure of tree natural regeneration, dieback in old or ageing oak stands and loss of biodiversity are some of the most common threats (Pulido and Díaz 2005; Eichhorn et al. 2006; Moreno and Pulido 2009; Mosquera-Losada et al. 2012). The increase in density and cover of a third vegetation layer composed of shrubs in zones formerly devoid of these plants has also been highlighted as a symptom of degradation (Acacio et al. 2007). Other authors, however, have shown the positive effects of encroachment on the functions of silvopastoral systems, such as natural regeneration of trees (Ramírez and Díaz 2008), diversification of animal diet (Patón 2003), erosion control (Lavado et al. 2004) and biodiversity conservation (Díaz et al. 2003). As a consequence, temporary abandonment and subsequent shrub encroachment have been proposed as a more costeffective tool than artificial plantation to enhance natural recruitment of trees (Pulido et al. 2010). This type of dehesa management involves creating a mosaic-type farm and landscape according to a long-term rotation plan, habitual in the past, where forest and encroached plots are mixed with more intensively grazed plots.

Shrub-pasture and shrub-tree interactions are little studied. Studies on shrublands have shown that shrubs may have a similar effect on pasture production to the effect of trees on open woodlands because of their positive effect on microclimate, soil erosion and organic matter accumulation (Moreno and ObradorOlán 2007; Ruiz-Peinado et al. 2013). It can therefore be assumed that shrubs play a positive role in dehesa productivity. However, it has also been shown that shrubs may compete with trees and pasture for soil resources, nutrients and water (Moreno et al. 2007; Rolo and Moreno 2011; Sircely and Naeem 2013).

Complex interactions between plants and the high variety of shrub species, cover and morphologies in encroached dehesa plots make it difficult to generalise conclusions and recommendations about the role of shrubs in dehesas. Rivest et al. (2011a) detected that herbaceous understory is influenced by trees and shrubs in different directions and intensities, but detailed information on the spatial extent of this influence is not available. There is also a lack of integrative studies on forage resources in dehesas or other extensive silvopastoral systems and the extent to which processes of land-use change, such as shrub encroachment, can affect the productivity of the whole system.

After shrub encroachment, total aboveground net primary productivity increases mainly because of changes in shrub biomass (Castro and Freitas 2009). However, the consequences of this energy input on livestock production are unknown. The pasture value of forage depends not only on its production but also on its quality (i.e., nutritional value). One of the most important parameters used to determine the quality of food is its metabolisable energy (ME) (Allen et al. 2011). The ME content of forage can give a reasonable indication of animal performance (Waghorn and Clark 2004) and provide a more relative method of comparing grassland productivity than the use of dry-matter yield (Tallowin and Jefferson 1999).

The aim of this study was to investigate the effects of dehesa encroachment on the total productivity of the Iberian dehesa (based on scattered Quercus ilex trees) by taking into account shrub and tree browse, acorn production and pasture production to calculate the overall ME under different scenarios of vegetation structure. Two shrub species with contrasting plant architectures were studied as models. Cistus ladanifer L. ("Cistus") has leafy stems and edible fruits, and forms extensive and mostly aggregated populations with shallow, dense root systems. Retama sphaerocarpa (L.) Boiss ("Retama") is a leguminous shrub with $\mathrm{N}_{2}$-fixing capabilities that normally grows in scattered populations. Retama develops a dimorphic root system with long area lateral roots and deep roots that allow the plant to tap deep water sources. The information gained through this study will help to define better management practices by combining traditional twolayered plots with three-layered plots, where shrubs facilitate tree regeneration without a noticeable loss of forage productivity. 


\section{Materials and methods}

Study area and system

The study was conducted from 2007 to 2010 in several dehesas of Quercus ilex L. in the north of the Extremadura region, in the mid-western region of Spain, 275 to 632 metres above sea level (m.a.s.l.) in the Mediterranean Biogeographic region (Europe). The climate of the area is Mediterranean, with hot, dry summers and mild, rainy winters. Mean annual precipitation is $550-600 \mathrm{~mm}$ and mean annual temperature is $15-16^{\circ} \mathrm{C}$. A period of drought usually occurs from June to September. Dehesa soils are mostly classified as Dystric Cambisols (Moreno et al. 2013) and are moderately deep $(50-100 \mathrm{~cm})$ with slightly acidic $\mathrm{pH}(5.0-5.5)$ and low cation exchange capacity.

For this study, 40 dehesa farms ("site") were selected: 20 with a Retama understory and 20 with a Cistus understory. Each site had two adjacent plots differing in the presence or absence of a shrub understory (encroached plot and control plot, respectively). Mean diameter at breast height (dbh) was $45 \mathrm{~cm}$ in the dehesas with Cistus and $49 \mathrm{~cm}$ in the dehesas with Retama. On average, crown diameter and tree density were $9.93 \mathrm{~m}$ and 29 trees $^{-1}$ on Cistus dehesas and $12.3 \mathrm{~m}$ and 24 trees $\mathrm{ha}^{-1}$ on Retama dehesas. Encroached plots on the Retama sites had an average shrub cover of $34.0 \%$ and an average shrub height of $1.8 \mathrm{~m}$. Encroached plots on the Cistus sites had an average shrub cover of $77.5 \%$ and an average shrub height of $1.9 \mathrm{~m}$. Tree size and cover, soil type and slope were very similar within each pair of adjacent plots. The herbaceous layer is dominated by native Mediterranean herbaceous species, particularly grasses (Avena sativa L., A. sterilis L. and Bromus hordeaceus L.), legumes (Ornithopus compressus L. and Trifolium resupinatum L.), and forbs (Taraxacum officinale Weber ex Wigg. and Stellaria media (L.) Vill.).

\section{Production assessments}

At selected sites, production of pasture, acorns, tree leaves, Cistus sprouts and fruits, and Retama fruits was determined. Acorn production was sampled in autumn 2007, 2008 and 2009 on 20 sites. At each site, 20 trees were studied (10 trees with shrub understory and 10 without). Beneath the crown of each sampled tree, fallen acorns and lignified cupules were collected in four randomly positioned $0.5 \times 0.5 \mathrm{~m}$ quadrants (each located in the four cardinal directions) and bulked into one composite sample per tree (Rivest et al. 2011a). It was assumed that annual production of tree browse biomass is roughly equivalent to annual leaf production. Because the turnover rate is the inverse of the leaf life span, annual leaf production can be calculated by dividing the standing leaf biomass by its leaf life span (Mediavilla and Escudero 2003). Montero et al. (2005) determined the total leaf weight of $Q$. ilex growing in Iberian dehesas as a function of tree dbh (diameter at breast height). Mediavilla and Escudero (2003) reported a mean leaf life span of 2.11 years for $Q$. ilex in the two-layered dehesas of Western Spain. For the control plots, annual leaf production per tree was estimated from tree leaf biomass (estimated from tree dbh at 40 sites, 10 trees per site) divided by 2.11 . To account for the effect of shrubs on annual tree browse production, the ratio of annual shoot elongation in trees growing in encroached plots compared to trees growing in the control plots was considered (Rivest et al. 2011a). Shrub browse production was determined in spring 2008 by measuring annual sprout and fruit biomass, which were considered the browse products of both shrubs (young sprouts+fruits for Cistus; fruits for Retama). Production was quantified at 18 sites (nine with Cistus and nine with Retama) along three transects $(50 \times 4 \mathrm{~m})$ randomly located at each site. Additionally, three plants from each transect were cut, weighed and oven-dried $\left(80^{\circ} \mathrm{C}\right.$ for $48 \mathrm{~h}$ ) (RuizPeinado et al. 2013).

To determine pasture production (referring to herbaceous plants), six sites were selected (three with Cistus and three with Retama). On each Cistus site, 12 trees were selected: six with shrub understory and six without. Pasture production in the presence of livestock was measured inside exclusion cages $(1 \times 1 \mathrm{~m})$. Although a gradient of pasture production should be expected from the tree to the open areas, earlier studies showed that this gradient is quite sharp and limited to a very short distance beyond the crown projection (Gea-Izquierdo et al. 2010). Exclusion cages were therefore located at only two distances for pasture collection: beneath the tree canopy and $10 \mathrm{~m}$ beyond tree crowns. On the Retama sites, the experimental design was changed 
because of the scarcity of shrubs beneath the trees. Therefore, eight trees were selected and pasture exclusion cages were placed in three different positions: beneath the crown, beyond the trees in areas without shrubs and beyond the trees in areas with a shrub layer (Rivest et al. 2011a). All cages were harvested in May and November 2007-2010. Additionally, on the same sites used for pasture production measurement, it was determined whether the influence of shrubs on pasture production varied with distance from the shrubs. In spring 2010 (before livestock entered), pasture samples were taken using quadrants $(15 \times 20 \mathrm{~cm})$ at various distances (nine for Cistus; 10 for Retama) from single shrub plants (Fig. 1). The difference in the sample number was due to differences between species size. In each case, 15 plants were sampled (five on each site). The first sample was harvested proximal to the innermost circle (around the base of stems) and the last sample was located well beyond the shrub canopy. For Retama, it was assumed that pasture production in the innermost circle (I; a circle approximately $35 \%$ of the crown) was similar to the first sample $(0-0.15 \mathrm{~m})$. For Cistus, there was no pasture production in the innermost circle ( $25 \%$ of the crown). In all cases, samples were located randomly.
Calculations and data analysis

The first step was to calculate the influence of shrubs on pasture production by applying a nonlinear least squares fit (Levenberg-Mardquart) with a Boltzmann function,

$P(d)=a_{0}+\frac{a_{1}-a_{0}}{1+\exp \left(\frac{d-d_{0}}{\Delta}\right)}$

performed using the $\mathrm{R}$ statistical programming language (www.r-project.org), where $P$ is production (in $\mathrm{Mg} \mathrm{ha}^{-1}$ ) and $d$ is the distance (in $\mathrm{cm}$ ) to the centre of the plant. Nonlinear models were fitted using R ( R Core Team 2013). Pasture production on a hectare scale was then calculated by multiplying the effects of trees and shrubs on pasture production by generating a grid of $10^{6}$ pixels per hectare and estimating pasture production at each pixel based on the distance to neighbouring trees and shrubs. For the tree effect, pixels were classified as either inside or outside the tree canopy projection. For the shrub effect, the Boltzmann functions were applied. To determine the distance of pixels in relation to trees and shrubs, a regular distribution of both layers was assumed.

The effect of tree and shrub density on acorn production based on area $\left(\mathrm{m}^{2}\right.$ of canopy) was
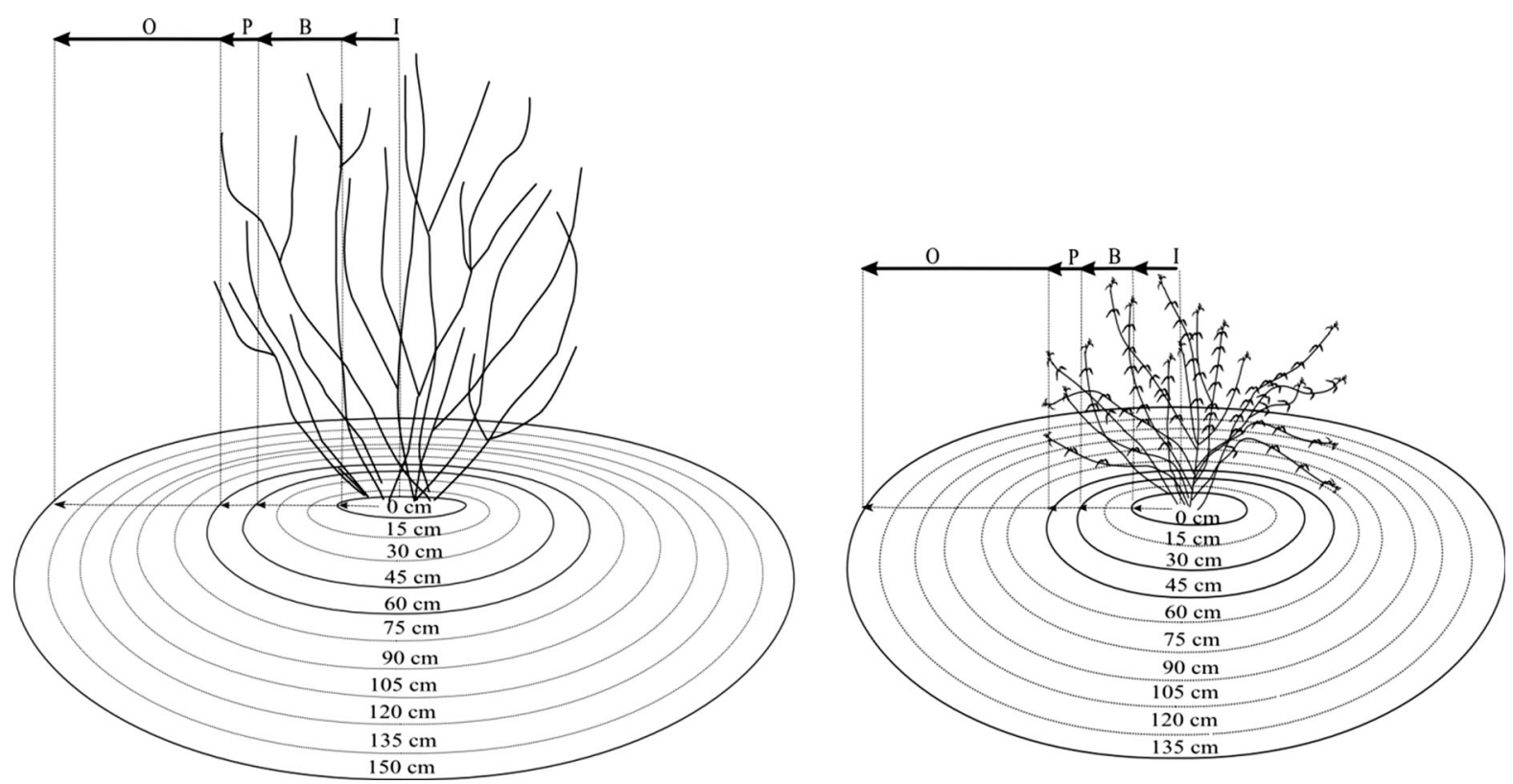

Fig. 1 Shrub sampling design to determine the area of pasture influenced by Retama (left) and Cistus (right). $C$ plant centre, $I$ innermost circle of the crown, $B$ beneath the shrub, $P$ periphery of the shrub, $O$ outside shrub cover 
determined by multiple linear regression, with tree cover $(\%)$ and shrub cover (\%) as factors and acorn production ( $\mathrm{g} \mathrm{m}^{-2}$ of canopy cover) as a response variable ( $\mathrm{n}=20$ sites). Changes in leaf biomass and shrub forage biomass with tree and shrub cover were also estimated by multiple linear regression.

For each forage resource (pasture, acorns, tree browse and shrub browse), annual biomass production $\left(\mathrm{kg} \mathrm{ha}^{-1}\right)$ was multiplied by the respective ME ratio $\left(\mathrm{MJ} \mathrm{kg}^{-1}\right)$, which gave the ME produced by each resource $\left(\mathrm{MJ} \mathrm{ha}{ }^{-1}\right)$. By adding these four partial $\mathrm{ME}$ values, the total ME produced per hectare was calculated. Based on earlier publications (Martín Polo et al. 2003; Patón et al. 2004; Robles et al. 2008), the following ME ratios were assumed: 10.3, 5.82, 6.59, 10.4 and $8.8 \mathrm{MJ} \mathrm{kg}^{-1} \mathrm{MS}$ for acorns, $Q$. ilex leaves, Cistus sprouts, Retama and pasture, respectively. ME was estimated for hypothetical sites with cover of 0 to $100 \%$, with a step of $10 \%$ for both trees and shrubs combined factorially.

Shrub encroachment effects on acorn yield, annual tree leaf production and pasture production were determined using GLMMs, with site as random factor, shrub understory presence (control vs. shrub-encroached plot) as fixed factor and production in successive years as repeated measures. The lme 4 package of the $\mathrm{R}$ software (R Core Team 2013) was used.

\section{Results}

Acorn and tree browse production

Acorn, tree and shrub browse, and pasture production $\left(\mathrm{kg} \mathrm{ha}^{-1}\right)$ are shown in Tables 1 and 2 for both control and shrub-encroached plots. In general, acorn production was negatively affected by Cistus presence ( 280.0 vs. $183.7 \mathrm{~kg} \mathrm{ha}^{-1}$ in control and shrub-encroached plots as mean value for the three years, respectively), suggesting a decrease in acorn production of $34.4 \%$ with shrub presence. However, no significant differences were observed between Retama-encroached plots and control plots.

Following allometric equations published by Montero et al. (2005), the estimated weight of tree leaves was $32 \mathrm{~kg}$ tree $^{-1}$ (Cistus; mean tree $\mathrm{dbh}$ of $45 \mathrm{~cm}$ ) and $37.84 \mathrm{~kg}$ tree $^{-1}$ (Retama; mean tree dbh of $49 \mathrm{~cm}$ ). Annual leaf production was calculated by dividing these values by 2.11 [mean leaf life span; Mediavilla and
Escudero (2003)]. Taking into account the differences in annual shoot growth caused by the presence of shrubs, the values obtained decreased by $27.3,16.6$ and $19.7 \%$ in 2007, 2008 and 2009, respectively, in the presence of Cistus, and increased by $12.8,4.5$ and $5.4 \%$ in 2007, 2008 and 2009, respectively, in the Retama plots. The weight of leaves annually available for livestock was $439.81 \mathrm{~kg} \mathrm{ha}^{-1}$ year (control) versus $346.45 \mathrm{~kg} \mathrm{ha}^{-1}$ year (Cistus-encroached plots) and $430.41 \mathrm{~kg} \mathrm{ha}^{-1}$ year (control plot) versus $463.06 \mathrm{~kg} \mathrm{ha}^{-1}$ year (Retama-encroached plots).

Shrub browse production

Encroached plots showed a mean shrub cover, height and crown radius of $53.65 \%, 1.63 \mathrm{~m}$ and $0.59 \mathrm{~m}$, respectively, in the Cistus treatments, and $37.85 \%, 1.7 \mathrm{~m}$ and $0.91 \mathrm{~m}$, respectively, in the Retama treatments. Mean shrub browse production was $704.3 \mathrm{~kg} \mathrm{ha}^{-1}$ (young stems+leaves+fruit and $9.8 \%$ aboveground biomass) in Cistus-encroached plots, and $57.9 \mathrm{~kg} \mathrm{ha}^{-1}$ (only fruit and $1.9 \%$ aboveground biomass) in Retama-encroached plots (Tables 1, 2).

Pasture production

The results of the Boltzmann fit (Table 3; Fig. 2) showed that pasture production decreased rapidly from the vicinity of the Cistus plants to the innermost circle, where it stabilised at very low values. The opposite was found for Retama, which showed increased pasture production beneath the canopy. According to the Boltzmann fits, four zones of influence can be defined: the interior of the shrub (I); area with the highest influence in pasture production below the shrub $(\mathrm{H})$; area with an intermediate shrub influence (L); and area without shrub influence (W). Zone $\mathrm{H}$ covered an area of $0.69 \mathrm{~m}^{2}$ plant $^{-1}$ (Cistus) and $0.72 \mathrm{~m}^{2}$ plant $^{-1}$ (Retama), indicating that the highest influence was detected at 0.49 and $0.48 \mathrm{~m}$ (Fig. 2) from the plant centre for Cistus and Retama, respectively. Zone L covered $1.73 \mathrm{~m}^{2}$ plant $^{-1}$ (Cistus; $0.89 \mathrm{~m}$ radius from the plant centre) and $1.15 \mathrm{~m}^{2}$ plant $^{-1}$ (Retama; $0.77 \mathrm{~m}$ radius from the plant centre). These data indicate that the total area of influence $(\mathrm{H}+\mathrm{L})$ of Cistus plants was greater than the mean crown size (1.09 and $2.60 \mathrm{~m}^{2}$ for Cistus and Retama, respectively), whereas this effect did not go beyond the crown in Retama plants. 
Table 1 Acorn, tree and shrub browse, and pasture production $\left(\mathrm{kg} \mathrm{ha}^{-1}\right.$ year) in relation to Cistus presence

Data refer to average stands, with 29 trees ha ${ }^{-1}$, $22.5 \%$ tree cover and $75 \%$ Cistus cover

Means values are followed by $\pm 1 \mathrm{SE}$

$n s$ not-significant,

$* P<0.05, * * P<0.01$ *** $P<0.001$

\begin{tabular}{lllll}
\hline & Year & Control & Cistus & Sign \\
\hline Acorn & 2007 & $363.78 \pm 51.3$ & $211.3 \pm 27.43$ & $* *$ \\
& 2008 & $150.99 \pm 16.11$ & $141.30 \pm 20.21$ & $\mathrm{~ns}$ \\
Tree browse & 2009 & $325.25 \pm 26.37$ & $198.48 \pm 27.76$ & $* * *$ \\
& 2007 & $439.81 \pm 17.46$ & $319.65 \pm 13.81$ & $* * *$ \\
Shrub browse & 2008 & $439.81 \pm 22.65$ & $366.67 \pm 26.25$ & $*$ \\
Pasture & 2009 & $439.81 \pm 18.69$ & $353.03 \pm 14.19$ & $* * *$ \\
& 2008 & 0 & 974.7 & \\
& 2007 & $2732 \pm 340$ & $1461 \pm 100$ & $* * *$ \\
& 2008 & $2342 \pm 470$ & $1,412 \pm 170$ & $\mathrm{~ns}(0.07)$ \\
& 2009 & $991 \pm 450$ & $470 \pm 90$ & $\mathrm{~ns}$ \\
\hline
\end{tabular}

Table 2 Acorn, tree and shrub browse, and pasture production $\left(\mathrm{kg} \mathrm{ha}^{-1}\right.$ year) in relation to Retama presence (mean shrub canopy: $37.85 \%$ )

Data refer to average stands, with 24 trees ha ${ }^{-1}$, $27.7 \%$ tree cover and 34

$\%$ Retama cover

\begin{tabular}{lllll}
\hline & Year & Control & Retama & Sign \\
\hline Acorn & 2007 & $339.86 \pm 43.31$ & $276.98 \pm 39.35$ & $\mathrm{~ns}$ \\
& 2008 & $133.74 \pm 14.21$ & $120.96 \pm 13.57$ & $\mathrm{~ns}$ \\
Tree browse & 2009 & $183.26 \pm 18.66$ & $216.34 \pm 33.10$ & $\mathrm{~ns}$ \\
& 2007 & $430.41 \pm 18.37$ & $485.54 \pm 25.25$ & $\mathrm{~ns}(0.08)$ \\
Shrub browse & 2008 & $430.41 \pm 26.27$ & $449.9 \pm 19.48$ & $\mathrm{~ns}$ \\
Pasture & 2009 & $430.41 \pm 19.54$ & $453.74 \pm 18.06$ & $\mathrm{~ns}$ \\
& 2008 & 0 & 55.3 & \\
& 2007 & $2354 \pm 223$ & $2553 \pm 216$ & $\mathrm{~ns}$ \\
& 2009 & $2376 \pm 324$ & $2483 \pm 262$ & $\mathrm{~ns}$ \\
& 2010 & $1576 \pm 150$ & $403 \pm 37$ & $\mathrm{~ns}$ \\
\hline
\end{tabular}

Table 3 Results of the nonlinear least square fit to a Boltzmann function to pasture production around both type of shrubs (Cistus and Retama)

\begin{tabular}{|c|c|c|c|c|c|c|}
\hline \multirow[t]{2}{*}{ Parameter } & \multicolumn{3}{|l|}{ Cistus } & \multicolumn{3}{|l|}{ Retama } \\
\hline & Value & Std. error & $P$ value & Value & Std. error & $\mathrm{P}$ value \\
\hline$a_{0}$ & 1.37071 & 0.05065 & $1.29 \mathrm{e}-06$ & 2.09833 & 0.06706 & $7.07 \mathrm{e}-08$ \\
\hline$a_{1}$ & 0.41141 & 0.06294 & 0.00125 & 1.56579 & 0.01916 & $2.26 \mathrm{e}-10$ \\
\hline$d_{0}$ & 68.74560 & 3.59231 & $7.18 \mathrm{e}-06$ & 62.60970 & 4.53921 & $9.03 e-06$ \\
\hline \multirow[t]{2}{*}{$\Delta$} & 14.63427 & 3.56657 & 0.00933 & -11.06893 & 3.60382 & 0.0219 \\
\hline & \multicolumn{3}{|c|}{$R^{2}=0.9863178$} & \multicolumn{3}{|c|}{$R^{2}=0.9722854$} \\
\hline
\end{tabular}

The values calculated for the sites studied are shown in Tables 1 and 2. The presence of Cistus significantly reduced pasture production (34.8\% in 2010 to $46.5 \%$ in 2007). However, no significant differences were observed on the Retama plots, even though the values were slightly higher with shrub presence (403-2553 $\mathrm{kg} \mathrm{ha}^{-1}$ ) than in the control (359-2376 $\left.\mathrm{kg} \mathrm{ha}^{-1}\right)$.

\section{Metabolisable energy}

Adding the ME of the forage types available at each study site (Table 4) showed that ME increased with the presence of Retama $(21,050.4$ vs. 19,423.2 $\mathrm{MJ} \mathrm{ha}^{-1}$ year $^{-1}$ in the control). However, the ME of the Cistus-encroached plots decreased 


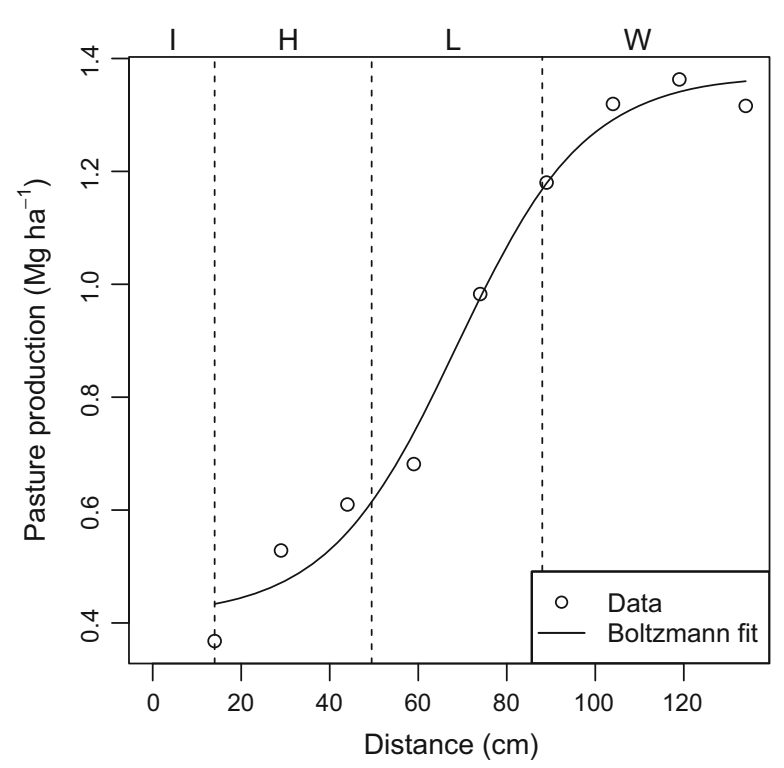

Fig. 2 Pasture production $\left(\mathrm{Mg} \mathrm{ha}^{-1}\right.$ year $\left.^{-1}\right)$ at varying distances from mean-size Cistus (left) and Retama (right) plants. The origin of the $\mathrm{x}$-axis represents the plant centre. Types of influence close to shrubs: area with the highest influence on pasture production below the shrub $(\mathrm{H})$; area with an intermediate shrub influence (L); and area without shrub

Table 4 Metabolisable Energy (ME; MJ ha ${ }^{-1}$ year $^{-1}$ ) and percentage of $\mathrm{ME}(\% \mathrm{ME})$ in relation to total production with shrubs (Cistus and Retama) and without shrubs (Control)

\begin{tabular}{llllll}
\hline & & Control & Cistus & Control & Retama \\
\hline Acorn & ME & 2884 & 1892 & 2255 & 2109 \\
& \% ME & 12.6 & 9.5 & 11.6 & 10.0 \\
Tree browse & ME & 2560 & 2016 & 2505 & 2695 \\
& $\% \mathrm{ME}$ & 11.2 & 10.1 & 12.9 & 12.8 \\
Shrub browse & ME & 0.00 & 5967 & 0 & 617 \\
& $\% \mathrm{ME}$ & 0.0 & 30.0 & 0 & 2.9 \\
Pasture & ME & 17,384 & 9,990 & 14,663 & 15,644 \\
& $\% \mathrm{ME}$ & 76.15 & 50.3 & 75.5 & 74.3 \\
Total ME & & $\mathbf{2 2 , 8 2 8}$ & $\mathbf{1 9 , 8 6 5}$ & $\mathbf{1 9 , 4 2 3}$ & $\mathbf{2 1 , 0 6 5}$ \\
\hline
\end{tabular}

Bold letters were used to emphasize the values of the total ME

more than in the control plots $(18,539.9$ vs. 22,828.2 $\mathrm{MJ} \mathrm{ha}^{-1}$ year $^{-1}$ ) (Table 4).

Table 5 shows the best fits obtained for the estimate of annual ME for each forage category according to tree and shrub cover. In all cases, the dependence of annual ME on shrub and tree cover can be described as the product of the individual dependences of annual $\mathrm{ME}$ on the shrub cover (for any fixed value of tree

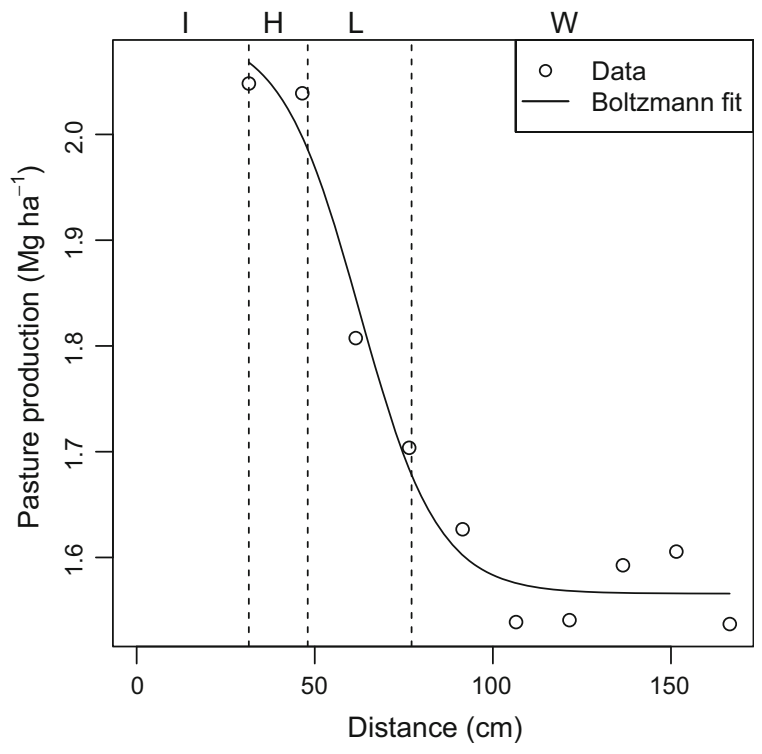

influence (W). For Retama, pasture production in the innermost circle (I; a circle approximately $35 \%$ of the crown) was similar to the first sample $(0-0.15 \mathrm{~m})$. For Cistus, there was no pasture production in the innermost circle (I; $25 \%$ of the crown). Equations are shown in Table 3

cover) and the tree cover (for any fixed value of shrub cover). Expressions were fitted in the form $E\left(C_{S}\right.$, $\left.C_{T}\right)=F_{1}\left(C_{S}\right) F_{2}\left(C_{T}\right)$. Dependence on shrub cover was always linear, except for shrub forage, where it followed a power law. Tree cover dependence followed certain power laws with the exception of pasture, where dependence of annual ME on tree cover followed certain exponential decay patterns. The equations show that the annual ME supplied by acorns and tree leaves increased almost linearly with tree density $(\beta=0.8472)$, but acorns peaked at approximately $70 \%$ of tree cover and then decreased to $\sim 25 \%$ of the maximum (Beta function pattern). In both cases, Cistus and Retama shrub cover reduced ME slightly and linearly. The ME supplied by shrubs increased almost linearly with shrub cover, but tended to stabilise at high shrub cover $(b=0.6675)$. The tree effect was negligible for ME production of Cistus until ca. $70 \%$ tree cover; above this threshold (dense woodlands), ME production decreased rapidly (following a decreasing power law). For Retama, this threshold was found at ca. $50 \%$ tree cover. The ME supplied by pasture decreased rapidly with Cistus presence, and above $\sim 50 \%$ cover, ME remained almost constantly low. With tree cover, ME decreased 
Table 5 Equations for the estimate of annual Metabolisable Energy production $\left( \pm \mathrm{CI}_{95} \%\right.$; $\mathrm{MJ}^{-1}$ year $)$ in four forage categories: acorns, tree leaves, shrubs and pasture

\begin{tabular}{|c|c|c|c|c|}
\hline Forage type & Fit func & ions & Dehesas with Cistus & Dehesas with Retama \\
\hline Acorn & $\begin{array}{l}F_{1}\left(C_{S}\right) \\
F_{2}\left(C_{T}\right)\end{array}$ & $\begin{array}{l}\text { Linear: }\left(b-a C_{S}\right) \\
\text { Beta function: } C_{T}^{\alpha}\left(100-C_{T}\right)^{\beta}\end{array}$ & $\begin{array}{l}a=0.0403 \pm 0.0382 \\
b=9.073 \pm 8.4947 \\
\alpha=1.206 \pm 0.155 \\
\beta=0.4623 \pm 0.0954\end{array}$ & $\begin{array}{l}a=0.00896 \pm 0.0045 \\
b=2.889 \pm 1.194 \\
\alpha=1.276 \pm 0.069 \\
\beta=0.5947 \pm 0.0426\end{array}$ \\
\hline Tree browse & $\begin{array}{l}F_{1}\left(C_{S}\right) \\
F_{2}\left(C_{T}\right)\end{array}$ & $\begin{array}{l}\text { Linear: }\left(b-a C_{S}\right) \\
\text { Power law: } C_{T}^{\beta}\end{array}$ & $\begin{array}{l}a=0.5359 \pm 0.0259 \\
b=193.2 \pm 7.2 \\
\beta=0.8472 \pm 0.0086\end{array}$ & $\begin{array}{l}a=0.2931 \pm 0.0558 \\
b=158.7 \pm 8.4 \\
\beta=0.8327 \pm 0.0118\end{array}$ \\
\hline $\begin{array}{l}\text { Shrub } \\
\text { browse }\end{array}$ & $\begin{array}{l}F_{1}\left(C_{S}\right) \\
F_{2}\left(C_{T}\right)\end{array}$ & $\begin{array}{l}\text { Power law: } a C_{S}^{b}\left(b-a C_{S}\right) \\
\text { Power law: }\left(100-C_{T}\right)^{\beta} C_{T}^{\beta}\end{array}$ & $\begin{array}{l}a=270.2 \pm 67.6 \\
b=0.6675 \pm 0.05 \\
\beta=0.1558 \pm 0.0335\end{array}$ & $\begin{array}{l}a=15.41 \pm 5.642 \\
b=0.5862 \pm 0.0645 \\
\beta=0.3698 \pm 0.1063\end{array}$ \\
\hline Pasture & $\begin{array}{l}F_{1}\left(C_{S}\right) \\
F_{2}\left(C_{T}\right)\end{array}$ & $\begin{array}{l}\text { Linear: }\left(1-a C_{S}\right) \\
\text { Exponential decay: } \\
\qquad A e^{-\alpha C_{T}}+B e^{-\beta C_{T}}\end{array}$ & $\begin{array}{l}a=3.02 \times 10^{-3} \pm 1.04 \times 10^{-4} \\
A=1.761 \times 10^{4} \pm 150 \\
\alpha=0.01213 \pm 1.65 \times 10^{-4} \\
B=\beta=0 \\
\text { (Single exponential) }\end{array}$ & $\begin{array}{l}a=- \\
2.005 \times 10^{-3} \pm 8.8 \times 10^{-5} \\
A=1.514 \times 10^{4} \pm 130 \\
\alpha=1.664 \times 10^{-3} \pm 1.13 \times 10^{-4} \\
B=1572 \pm 128 \\
\beta=0.1052 \pm 0.0186\end{array}$ \\
\hline
\end{tabular}

The ME corresponding to the different forage resources can be modelled with the same pattern function: $E\left(C_{S}, C_{T}\right)=F_{1}\left(C_{S}\right) F_{2}\left(C_{T}\right)$ where $F_{1}\left(C_{S}\right)$ describes the dependence of $\mathrm{ME}$ on the shrub cover (in $\%$ ) for any fixed value of tree cover and $F_{2}\left(C_{T}\right)$ describes the dependence of ME on the tree cover $(\%)$ for any fixed value of shrub cover

following a single exponential decay. The increment in ME with Retama cover partially compensated for the decrease caused by tree cover; in this situation, a double exponential decay dependence on tree density was observed.

Figure 3 shows the variation in total ME with different shrub and tree cover and the complex variations resulting from the diverse effects of tree and shrub cover for the forage types. Maximum ME was obtained for approximately $70 \%$ tree cover, with either $10 \%$ shrub cover for Cistus sites or $30 \%$ shrub cover for Retama sites.

\section{Discussion and conclusions}

Acorn and tree browse production

Acorn and tree browse production were negatively affected by Cistus presence. However, Retama presence improved tree browse production and had no significant effects on acorn production. It is hypothesised that the contrasting rooting profiles of
Cistus and Retama (Rolo and Moreno 2012) determined these differences.

Carevic et al. (2010) observed a close relationship between acorn productivity and the physiological state of oak trees. At the sites in the present study, the physiological status of scattered $Q$. ilex trees was monitored over three consecutive summers (Rolo and Moreno 2011). It was concluded that Cistus encroachment negatively affects the physiological state of $Q$. ilex, which would explain the decreased tree growth and acorn production observed. The dense root system of Cistus reported (Rolo and Moreno 2012) could take up a significant amount of water from the upper soil layers, preventing water and dissolved nutrients from percolating to greater depths where tree roots are concentrated (Rolo and Moreno 2012) and negatively affecting tree growth. This result could have been strengthened by the typically high shrub cover on plots in the present study (average $53.65 \%$ ).

In contrast, tree growth was significantly higher with Retama encroachment, because of improved soil conditions produced by this shrub (Delgado-Baquerizo et al. 2010; Rolo et al. 2012). However, the influence of Retama encroachment on acorn 

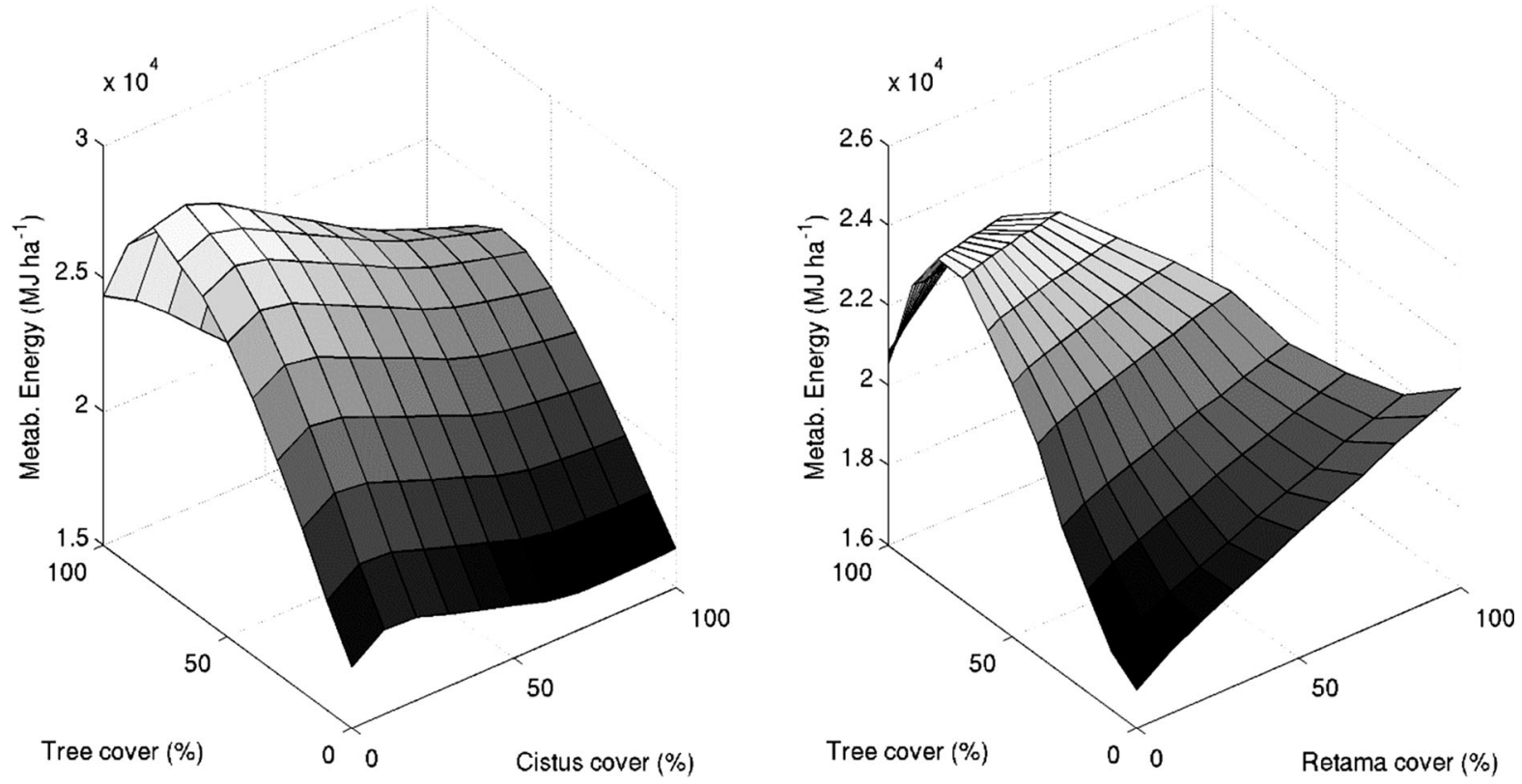

Fig. 3 Estimate of Metabolisable Energy $\left(\mathrm{MJ} \mathrm{ha}^{-1}\right.$ year) in relation to gradients of shrub cover [Cistus ladanifer (left) Retama sphaerocarpa (right)] and tree cover (Quercus ilex)

production was not significant. Soil water depletion in mid summer may have a negative effect on early acorn ripening and, ultimately, on acorn yield (Carevic et al. 2010). At the sites in this study, Rolo and Moreno (2011) reported a worsening of hydric status of trees growing among Retama by the end of summer, explained by the high spatial overlap of $Q$. ilex and deep Retama roots (Rolo and Moreno 2012).

\section{Shrub browse production}

In the Mediterranean basin, shrub browse can be a major source of forage complement to the diet of small ruminants, especially in places where these animals may face serious nutrient shortages (Platis and Papanastasis 2003; Ben Salem and Smith 2008; Ruiz-Mirazo et al. 2011). Most shrubs are drought tolerant and can accumulate green forage over several seasons, providing fodder reserves for times of scarcity when pasture supply is lacking. To determine the importance of shrubs as forage resources, it is necessary to take into account not only their feeding value (Parlak et al. 2011), but also biomass production.

Robles and González-Rebollar (2006) estimated the browse production of Retama in an ecosystem in southeast Spain. Browse production was assumed to be $50 \%$ of annual production, for which they reported a value of 2,229 kg ha ${ }^{-1}$ year $^{-1}$ (shrub cover: $69 \%$ ). This was much higher than the value obtained here $\left(57.9 \mathrm{~kg} \mathrm{ha}^{-1}\right.$ year $\left.^{-1}\right)$, partly because of the lower shrub cover in this study (34\%), but mostly because we considered only the fruit was edible. This assumption was based the authors' expertise and personal communication with local livestock breeders, who noted that common livestock species rarely browse Retama shoots. The utility of this species and similar leguminous shrubs deserves further research because of their high ME, positive effect on pasture production and quality (Rivest et al. 2011b; Rolo et al. 2014) and natural regeneration of dehesa tree species (Rolo et al. 2013).

Cistus grows in dense formations with high biomass per unit area, and cattle and goats can browse current year sprouts and fruit. According to the data, Cistus browse production $\left(704.3 \mathrm{~kg} \mathrm{ha}^{-1}\right)$ was higher than for Retama. However, whereas $C$. ladanifer can supply large amounts of forage resources, it is questionable whether livestock can graze these resources efficiently in dense and heterogeneous formations because of accessibility limitations (Etzenhouser et al. 1998). 
Pasture production

According to the literature, the effect of trees on pasture is mostly limited to the crown projection of $Q$. ilex (Moreno et al. 2007; Gea-Izquierdo et al. 2010). Although Moreno et al. (2007) reported a negative effect of trees on pasture yield, Gea-Izquierdo et al. (2010) reported a rather positive effect. The results of the present study confirmed a negative net effect of trees on pasture production. Cistus shrubs also had a very negative effect that projected beyond the plants (in an area $22 \%$ greater than mean crown size), although the influence decreased rapidly from the centre of the plant to the periphery. As result, with shrub density above $50 \%$ and regular distribution, the entire area of the plot was affected by the presence of this shrub, forming a fine mosaic of pasture yield. In contrast, the positive effect of Retama on grass production did not go beyond the crown of Retama plants. The affected area was $28 \%$ less than the mean crown size of these shrubs. These results show how the effect of the spatial extension of woody species on pasture production differs between species. This has important consequences for estimating the impact of tree and shrub presence on pasture production at the plot/farm scale.

The highest below-ground competition in the uppermost soil layer was between pasture and Cistus, as this is where most of their roots are found. Competition for resources such as the $\mathrm{N}$-mineral (Rolo and Moreno 2012) may have detrimental effects on pasture production. The allelopathic compounds found in Cistus tissues may also contribute to reduced pasture yields by inhibiting seed germination and root growth of annual herbaceous understory (Sosa et al. 2010). In the present study, distance-dependent equations were used to estimate pasture. The negative effects of Cistus did not appear to be so pronounced, because the highest suppression of pasture growth was limited to a small area (the innermost circle of crown projection).

Several studies of Mediterranean ecosystems have shown the potential of Retama for improving its own environment through positive feedback processes (e.g., protection from direct insolation and overheating and increases in soil organic matter, nitrogen content and mineralisation rates). This increases the aboveground biomass of the herbaceous understory (Moro et al. 1997; Rivest et al. 2011a). Prieto et al. (2010) also provided evidence to show that Retama is able to hydraulically lift and release water from deep to shallow soil layers during pronounced dry periods. However, when estimating pasture production at plot scale in this study, no significant response to the presence of Retama was observed. This could be explained because the positive influence of this shrub was limited to the innermost circle of Retama crown projection, with no effect in the outer area of the crown projection.

The estimate of pasture production at varying shrub and tree cover indicates the importance of system structure/management for pasture production. Pasture production with $100 \%$ tree cover is reduced to 70-75\% compared to open pasture. Maximum pasture production would be achieved by total Retama cover without trees (17\% increase over open pasture). Obviously, this approximation considered the added positive effects of Retama on pasture production and may have overestimated its effect at high values of cover beyond the range measured (60\% Retama cover). Rodríguez-Echeverría and Pérez-Fernández (2003) found higher values of pasture biomass growing under a single Retama shrub than at a high density of Retama. The accumulation of competitive effects at high density of woody plants may suppress rather than promote pasture production. In addition, in stressprone ambient conditions, thresholds that determine a shift in the effects of woody plants from positive to negative are common (Maestre et al. 2009). Therefore, the theoretical value of pasture production may not be accurate for values of woody cover beyond the range measured. Sampling schemes that consider the effect of various shrub encroachment scenarios on pasture production at different densities (stratified sampling) are recommended for a more reliable assessment of the effect of dense Retama formation on pasture production.

Metabolisable energy and vegetation structure

ME production was assessed under different system structures and the importance of tree and shrub cover for the entire forage resource was analysed. Overall, open pasture was less productive than plots partially covered by trees and/or Retama. Among the woody components, $Q$. ilex trees elicited the most positive effect on ME in the dehesas because of the provision of acorns and palatable leaves and the reduced negative 
effects of pasture understory growth. The effect of Retama cover was also positive for total ME production because of the slight increase in pasture production ( $2.86 \%$ in terms of ME) and the contribution of Retama fruit. In addition, Retama did not significantly affect acorn production when trees were present. According to the results, ME production is optimised with approximately $70 \%$ tree cover and $60 \%$ Retama cover. Under this structure, trees supply $41 \%$ of total ME (19\% from acorns and $22 \%$ from leaves), Retama supplies $1 \%$ and pasture supplies $58 \%$.

In contrast, the ME supplied by the Cistus strata did not compensate for the decrease in pasture and acorn production, because of the low ME supplied by this shrub. For farms with Cistus, the best option for ME production is to maintain a very low cover of this shrub (approximately $10 \%$ ) with a high density of trees (70-80\%). Under this structure, trees supply $51 \%$ of the total ME (24\% from acorns and $27 \%$ from leaves), Cistus supplies $7 \%$ and pasture supplies $42 \%$.

The results showed that woody pastures are more productive than open pastures, and shrubs can play a positive role in the forage productivity of Iberian dehesas by facilitating the production of pasture and/ or providing palatable resources, such as young sprouts and/or fruit. For both the Retama and Cistus shrubs, plots with a certain level of shrub cover were more productive than shrub-free plots, although browsing by livestock could be limited at high shrub cover. It is recommended that good management practices of Iberian dehesas and similar extensive silvopastoral systems should maintain the shrub layer (at optimal densities) to take advantage of the many positive roles of shrubs for ecosystem functioning (Eldridge et al. 2011) without compromising the overall productivity of the system.

Acknowledgments This study was funded by the Spanish Ministry of Science and Innovation (AGL2006-09435/FOR) and the Regional Government of Extremadura (PRI07C044).

\section{References}

Acacio V, Holmgren M, Jansen P, Schrotter O (2007) Multiple recruitment limitation causes arrested succession in Mediterranean cork oak systems. Ecosystems 10:1220-1230
Allen VG, Batello C, Berreta EJ, Hodgson J, Kothmann M, Li X, McIvor J, Milne J, Morris C, Peeters A, Sanderson M (2011) An international terminology for grazing lands and grazing animals. Grass Forage sci 66:2-28

Ben Salem H, Smith T (2008) Feeding strategies to increase small ruminant production in dry environments. Small Rumin Res 77(2-3):174-194

Carevic FS, Fernández M, Alejano R, Vázquez-Piqué J, Tapias R, Corral E, Domingo J (2010) Plant water relations and edaphoclimatic condicions affecting acorn production in a holm oak (Quercus ilex L. ssp. Ballota) open woodland. Agrofor Syst 78:299-308

Castro H, Freitas H (2009) Above-ground biomass and productivity in the Montado: from herbaceous to shrub dominated communities. J Arid Environ 73:506-511

Delgado-Baquerizo M, Castillo-Monroy AP, Maestre FT, Gallardo A (2010) Plants and biological soil crusts modulate the dominance of $\mathrm{N}$ forms in a semi-arid grassland. Soil Biol Biochem 42:376-378

Díaz M, Pulido FJ, Marañón T (2003) Diversidad biológica y sostenibilidad ecológica y económica de los sistemas adehesados. Ecosistemas 3 http://www.aeet.org/ ecosistemas/033/investigacion4.htm

Eichhorn MP, Paris P, Herzog F, Incoll LD, Liagre F, Mantzanas K, Mayus M, Moreno G, Papanastasis VP, Pilbeam DJ, Pisanelli A, Dupraz C (2006) Silvoarable systems in Europe-past, present and future prospects. Agrofor Syst 6:29-50

Eldridge DJ, Bowker MA, Maestre FT, Roger E, Reynolds JF, Whitford WG (2011) Impacts of shrub encroachment on ecosystem structure and functioning: towards a global synthesis. Ecol Lett 14(7):709-722. doi:10.1111/j.14610248.2011.01630.x.Epub

Etzenhouser MJ, Owens MK, Spalinger DE, Murden SB (1998) Foraging behavior of browsing ruminants in a heterogeneous landscape. Landscape Ecol 13:55-64

Gea-Izquierdo G, Allen-Díaz B, San Miguel A, Cañellas I (2010) How do trees affect spatio-temporal heterogeneity of nutrient cycling in mediterranean annual grasslands? Ann For Sci 67:112

Lavado JF, Schnabel S, Trenado R (2004) Comparison of resent land use and land cover changes in two dehesas agrosilvopastoral land use systems, SW Spain. Adv GeoEcol 37:57-70

Maestre FT, Callaway RM, Valladares F, Lortie CJ (2009) Refining the stress-gradient hypothesis for competition and facilitation in plant communities. J Ecol 97:199-205

Manning AD, Fischer J, Lindenmayer DB (2006) Scattered trees are keystone structures-implications for conservation. Biol Conserv 132:311-321

Martín Polo JL, García Bellido I, Sánchez Rodríguez E (2003) Plant production and nutritive quality of savannah-like grasslands (dehesas) in semi-arid zones of the province of Salamanca. Span J Agric Res 1(4):41-49

Mediavilla S, Escudero A (2003) Leaf life span differs from retention time of biomass and nutrients in the crowns of evergreen species. Funct Ecol 17:541-548

Montero G, Ruiz-Peinado R, Muñoz M (2005) Producción de biomasa y fijación de $\mathrm{CO}_{2}$ por los bosques españoles (Biomass production and $\mathrm{CO}_{2}$ sequestration by Spanish forest). INIA Monographs: serie forestal 13, p 270 
Moreno G, Obrador-Olán JJ (2007) Effects of trees and understorey management on soil fertility and nutritional status of holm oaks in Spanish dehesas. Nutr Cycl Agroecosyst 78:253-264

Moreno G, Pulido F (2009) The functioning, management and persistence of Dehesas. Adv Agrofor 6:127-160

Moreno G, Obrador JJ, García E, Cubera E, Montero MJ, Pulido F, Dupraz C (2007) Driving competitive and facilitative interactions in Oak Dehesas through management practices. Agrofor Syst 70:25-40

Moreno G, Bartolome JW, Gea-Izquierdo G, Cañellas I (2013) Overstory-understory relationships. In: Campos P, Huntsinger L, Oviedo JL, Starrs PF, Diaz M, Standiford RB, Montero G (eds) Mediterranean oak woodland working landscapes. Dehesas of Spain and Ranchlands of California., Landscape Series 16Springer, New York, pp 145-179

Moro MJ, Pugnaire FI, Haase P, Puigdefábregas J (1997) Mechanisms of interaction between a leguminous shrub and its understorey in a semi-arid environment. Ecography 20:175-184

Mosquera-Losada MR, Moreno G, Pardini A, McAdam GH, Papanastasis V, Burgess PJ, Lamersdorf N, Castro M, Liagre F, Rigueiro-Rodríguez A (2012) Past, present and future of agroforestry systems in Europe. In: Nair PKR, Garrity D (eds) Agroforestry-the future of global land use, advances in agroforestry. Springer, Dordrecht, pp 285-312. doi:10.1007/978-94-007-4676-3_16

Parlak AO, Gokkus A, Hakyemez BH, Baytekin H (2011) Forage quality of deciduous woody and herbaceous species throughout a year in mediterranean shrublands of Western Turkey. J Anim Plant Sci 21:513-518

Patón D (2003) Elaboration of a multivariate model for the determination of the metabolizable energy of mediterranean bushes based on chemical parameters. J Arid Environ 53(2):271-280

Patón D, Núñez J, Ranlo R, Alarcos S, Latorre E, Díaz MA (2004) Assessment of carrying capacity of Cistus spp. Shrubland for red deer (Cervus elaphus L.) management in Monfraguë Natural Park (SW Spain). In: Rangeland and pasture rehabilitation in Mediterranean areas, p 361-364. CIHEAM-IAMZ

Platis PD, Papanastasis VP (2003) Relationship between shrub cover and available forage in Mediterranean shrublands. Agrofor Syst 57:59-67

Prieto I, Kikvidze Z, Pugnaire FI (2010) Hydraulic lift: soil processes and transpiration in the Mediterranean leguminous shrub Retama sphaerocarpa (L.) Boiss. Plant Soil 329:447-456

Pulido FJ, Díaz M (2005) Recruitment of a Mediterranean oak: a whole-cycle approach. Ecoscience 12:99-112

Pulido F, García E, Obrador JJ, Moreno G (2010) Multiple pathways for tree regeneration in anthropogenic savannas: incorporating biotic and abiotic drivers into management schemes. J Appl Ecol 47:1272-1281

R Core Team (2013) R: a language and environment for statistical computing. R Foundation for Statistical Computing, Vienna

Ramírez JA, Díaz M (2008) The role of temporal shrub encroachment for the maintenance of Spanish holm oak Quercus ilex dehesas. For Ecol Manage 255:1976-1983
Rivest D, Rolo V, López-Díaz ML, Moreno G (2011a) Shrub encroachment in Mediterranean silvopsatoral systems: retama shaerocarpa and Cistus ladanifer induce contrasting effects on pasture and Quercus ilex production. Agric Ecosyst Environ 141:447-454

Rivest D, Rolo V, López-Díaz ML, Moreno G (2011b) Belowground competition for nutrients in shrub-encroached Mediterranean dehesas. Nutr Cycl Agroecosyst 90:347-354

Robles A, González-Rebollar JL (2006) Pastos áridos y ganado del sudeste de España. Sécheresse 17(1):309-313

Robles AB, Ruiz-Mirazo J, Ramos ME, González-Rebollar JL (2008) Role of livestock grazing in sustainable use, naturalness promotion in naturalization of marginal ecosystems of Southeastern Spain (Andalusia). Adv Agrofor 6:211-232

Rodríguez-Echevarría S, Pérez-Fernández MA (2003) Soil fertility and herb facilitation mediated by Retama sphaerocarpa. J Veg Sci 14:807-814

Rolo V, Moreno G (2011) Shrub species affect distinctively the functioning of scattered Quercus ilex trees in Mediterranean open woodlands. For Ecol Manage 261:1750-1759

Rolo V, Moreno G (2012) Interspecific competition induces asymmetrical rooting profile adjustments in shrub encroached open oak woodlands. Tree 26:997-1006

Rolo V, López-Díaz ML, Moreno G (2012) Shrubs affect soil nutrients availability with contrasting consequences for pasture understory and tree overstory production and nutrient status in Mediterranean grazed open woodlands. Nutr Cycl Agroecosyst 93:89-102

Rolo V, Plieninger T, Moreno G (2013) Facilitation of holm oak recruitment through two contrasted shrubs species in mediterranean grazed woodlands: patterns and processes. J Veg Sci 24:344-355

Rolo V, Rivest D, López-Díaz ML, Moreno G (2014) Microhabitat effects on herbaceous nutrient concentrations at the community and species level in Mediterranean open woodlands: the role of species composition. Grass Forage Sci. doi:10.1111/gfs. 12110

Ruiz-Mirazo J, Robles AB, González-Rebollar JL (2011) Twoyear evaluacion of fuel breals grazed by livestock in the wildfire prevention program in Andalusia (Spain). Agric Ecosyst Environ 141:13-22

Ruiz-Peinado R, Moreno G, Juárez E, Montero G, Roig S (2013) The contribution of two common shrub species to aboveground and belowground carbon pool in Iberian Dehesas. J Arid Environ 91:22-30

Sircely J, Naeem S (2013) Relationships of overstory trees and shrubs with forage species portray ecosystem service interactions in smallholder fallows. Agrofor Syst 87:451-464

Sosa T, Valares C, Alías JC, Chaves Lobón N (2010) Persistence of flavonoids in Cistus ladanifer soils. Plant Soil 337:51-63

Tallowin JRB, Jefferson RG (1999) Hay production from lowland semi-natural grasslands: a review of implications for ruminant livestock systems. Grass Forage Sci 54:99-115

Waghorn GC, Clark DA (2004) Feeding value for pasture in ruminants. N. Z. Vet J 2(6):320-331 